\title{
Pengungkapan Efektivitas Model Pembelajaran Melalui Anava Dua Faktorial
}

\author{
Tri Astuti Arigiyati. ${ }^{1}$ dan Istiqomah. ${ }^{2}$
}

\author{
1tri.astuti@ustjogja.ac.id \\ istiqomah@ustjogja.ac.id \\ ${ }^{I}$ Fakultas Keguruan dan Ilmu Pendidikan, Universitas Sarjanawiyata Tamansiswa \\ ${ }^{2}$ Fakultas Keguruan dan Ilmu Pendidikan, Universitas Sarjanawiyata Tamansiswa
}

\begin{abstract}
This study aims to determine the effectiveness of the learning model that is influenced by the level of students' initial abilities and the combined influence (interaction effect) between the learning model and the students' initial level of ability to the students' mathematics learning outcomes. The learning model has a central function in learning, namely as a tool and a way to achieve learning goals. The type of research used in this study is a quasi-experimental. The research subjects used as the subject of the trial were Yogyakarta State and Private Middle School Students. The object of this research is the students' initial abilities and learning outcomes of mathematics by using Write and Conventional Think Talk learning models. Data collection techniques used are test techniques and documentation techniques. Data were analyzed by two factors, both for initial ability test scores and learning outcome test scores and post anava test using Scheffe Test. The results of the study with $\alpha=5 \%$ indicate: 1) The Think Talk Write learning model is more effective than the conventional learning model. (2) Learning outcomes of high-skilled students are better than students who have moderate and low initial abilities, and (3) there is no interaction between learning methods and students' initial level of ability based on learning outcomes.
\end{abstract}

Keywords: Effectiveness, Think Talk Write, Anava

\section{Pendahuluan}

Keberhasilan seorang guru dalam mengajar dipengaruhi oleh banyak faktor, diantaranya adalah model pembelajaran yang digunakan guru saat mengajar di kelas. Sebagai calon guru, mahasiswa prodi pendidikan matematika FKIP UST harus mampu memilih dan menggunakan model pembelajaran yang tepat dalam menyampaikan materi. Penggunaan model pembelajaran yang tepat ini sangat bermanfaat untuk menumbuhkan pemahaman konsep siswa terhadap matematika. Konsep matematika yang abstrak, jika dikemas menarik dengan menerapkan model pembelajaran yang menarik dan menyenangkan akan menjadi lebih mudah. Melihat realitas yang ada, mahasiswa Prodi Pendidikan Matematika yang sedang menyusun tugas akhir skripsi seringkali melakukan penelitian ekperimen yaitu membandingkan dua atau lebih model pembelajaran. Penelitian yang dilakukan mahasiswa bertujuan untuk mengetahui model pembelajaran mana yang lebih efektif dibandingkan model pembelajaran yang lainnya. Salah satu model pembelajaran yang sering diteliti oleh mahasiswa adalah model pembelajaran 
koopertif tipe Think Talk Write (TTW) dibandingkan dengan model pembelajaran konvensional.

Apabila hanya melibatkan dua model pembelajaran maka analisis statistik yang dipergunakan adalah uji $\mathrm{t}$ beda rata-rata. Meskipun uji $\mathrm{t}$ adalah statistik yang sering digunakan, hanya saja uji t dibatasi untuk menguji hipotesis dua kelompok. Uji Anova atau Analisis varians (Anava) dikembangkan untuk memungkinkan peneliti menguji hipotesis perbandingan lebih dari dua kelompok. Dengan demikian, uji-t dan uji anava adalah sama-sama model statistik untuk perbandingan. Yang membedakan keduanya adalah hanya jumlah kelompok yang dibandingkan (Huang, 2017).

Analisis varians banyak digunakan pada penelitian-penelitian yang melibatkan pengujian komparatif yaitu menguji variabel terikat dengan cara membandingkannya pada kelompok-kelompok sampel independen yang diamati. Analisis varian saat ini banyak digunakan dalam penelitian survey dan penelitian eksperimen.

Analisis varians relatif mudah dimodifikasi dan dapat dikembangkan untuk berbagai bentuk percobaan yang lebih rumit. Selain itu, analisis ini juga masih memiliki keterkaitan dengan analisis regresi. Akibatnya, penggunaannya sangat luas di berbagai bidang, mulai dari eksperimen laboratorium hingga eksperimen periklanan, psikologi, dan kemasyarakatan.

Model pembelajaran Kooperatif Tipe TTW mungkin lebih efektif untuk siswa yang mempunyai kemampuan awal tinggi daripada siswa yang mempunyai kemampuan awal sedang dan atau rendah. Anava satu faktor tidak dapat mengungkapkan efek interaktif antar model pemeblajaran dengan tingkat kemampuan awal siswa. Analisis yang dapat mengungkapkan adalah analisis dua faktor atau rancangan faktorial. Rancangan ini pertama kali dikembangkan oleh R.A. Fisher dalam bidang pertanian (Kennedy and Bush dalam Usman 2009). Adapun keuntungan lain penggunaan rancangan faktorial, dapat meningkatkan sigifikansi perbedaan efektivitas dua model pembelajaran (Moortgart dalam Arcana, 2017).

Mahasiswa Prodi Pendidikan Matematika FKIP UST selalu menerapkan uji t dalam menganalisis data tentang efektivitas dua model pembelajaran. Seperti yang diuraikan di atas, uji $\mathrm{t}$ dan anava satu faktor tidak mampu mengungkapkan apakah efektivitas model pembelajaran dipengaruhi oleh kemampuan awal siswa atau tidak. Artikel ini akan mengungkap efektitivas model pembelajaran melalui anava faktorial, sehingga tujuan dari penelitian ini adalah untuk mengetahui efektivitas model pembelajaran yang dipengaruhi tingkat kemampuan awal siswa dan untuk mengetahui adanya pengaruh gabungan (efek interaksi) antara model pembelajaran dan tingkat kemampuan awal siswa terhadap hasil 
belajar matematika siswa.

Kemampuan awal dan hasil belajar dipilih menjadi obyek dalam penelitian ini karena hasil belajar erat kaitannya dengan hasil belajar. Monaghan berpendapat "Of course a person's understanding will always influence their problem solving (in any domain)". Pendapat ini memberikan makna bahwa cara penyelesaian masalah setiap orang dipengaruhi oleh pemahaman awalnya sehingga berpengaruh pula terhadap hasil belajarnya. (Ria Tri Krisnawati, 2011)

\section{Metode Penelitian}

Jenis penelitian yang digunakan dalam penelitian ini adalah eksperimen semu. Dikatakan eksperimen semu karena peneliti tidak mungkin untuk mengontrol semua variabel yang relevan (Tri Suwarni Widayati, 2009). Menurut Danim (dalam Syofian Siregar, 2012) penelitian eksperimen adalah penelitian dalam melakukan sebuah studi yang obyektif, sistematis, dan terkontrol untuk memprediksi atau mengontrol fenomena. Penelitian eksperimen bertujuan untuk menyelidiki hubungan sebab akibat, dengan cara mengekspos satu atau lebih kelompok eksperimental dan satu atau lebih kondisi eksperimen. Hasilnya dibandingkan dengan satu atau lebih kelompok kontrol yang tidak dikenai perlakuan. Desain penelitian ini berbentuk randomized pretest-posttest Control Group Design, yaitu desain kelompok kontrol pretes-postes yang melibatkan dua kelompok dan pengambilan sampel dilakukan secara acak kelas.

Subyek penelitian ini adalah Siswa Sekolah Menengah Pertama (SMP) Negeri dan Swasta Kota Yogyakarta sebanyak 5 sekolah. Sedangkan obyek penelitiannya adalah kemampuan awal siswa dan hasil belajar matematika dengan menggunakan model pembelajaran TTW dan model konvensional dengan metode ceramah. Sekolah yang dijadikan tempat penelitian adalah SMP N 11 Yogyakarta, SMP Taman Dewasa Ibu Pawiyatan Tamansiswa, dan SMP N 3 Yogyakarta. Penelitian dilakukan pada tahun pelajaran 2017/2018.

Alur penelitian disajikan pada diagram berikut: 


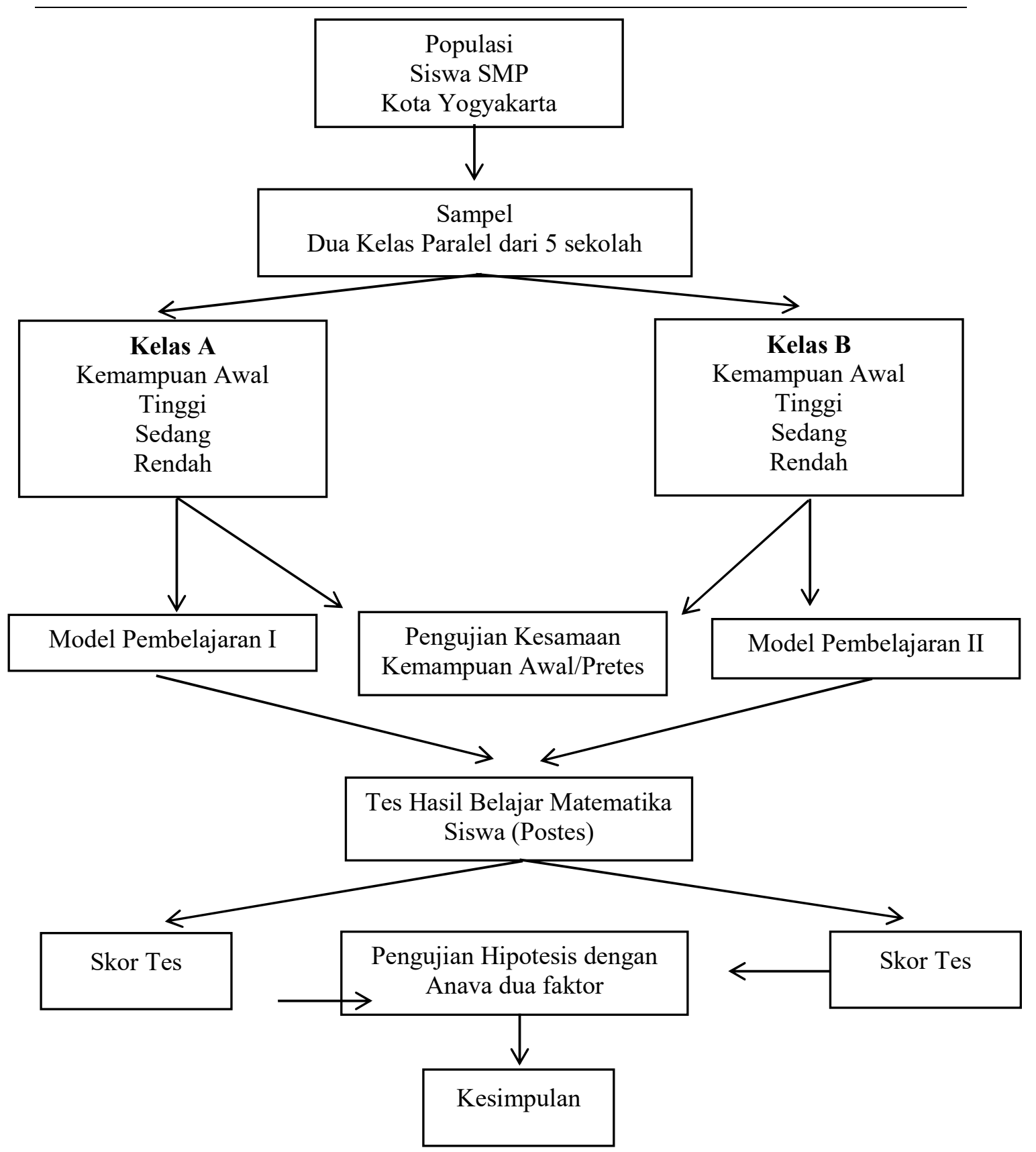

Gambar 1. Alur Penelitian

Teknik pengumpulan data yang digunakan adalah teknik dokumentasi dan teknik tes. Teknik dokumentasi digunakan untuk mengumpulkan data kemampuan awal, sedangkan teknis tes digunakan untuk mengumpulkan data hasil belajar matematika. Tes hasil belajar berbentuk pilihan ganda sebanyak 20 soal dengan 4 alternatif jawaban.

Uji coba instrumen yang dilakukan meliputi uji validitas item, daya beda butir, tingkat kesukaran, dan uji reliabilitas. Dari 20 soal yang diujicobakan terdapat 16 soal yang dikatakan baik, yaitu valid, memenuhi kriteria daya pembeda, tingkat kesukaran, dan reliabel. 
Data dianalisis dengan Anava dua faktor, baik untuk skor tes kemampuan awal maupun skor tes hasil belajar. Berkaitan dengan analisis ini akan dijelaskan hal-hal sebagai berikut: 1) Unit eksperimen adalah siswa, 2) Karakteristik yang diamati adalah hasil belajar matematika siswa, berupa skor tes, 3) Faktor A adalah model pembelajaran, terdiri dari 2 model yaitu model pembelajaran I (TTW) dan model pembelajaran II (Ceramah). Faktor B adalah tingkat kemampuan awal siswa, yang terdiri dari 3 tingkat (tinggi, sedang, rendah).

Namun sebelum data hasil belajar dianalisis, terlebih dahulu akan dilakukan uji prasyarat analisis yang meliputi uji keseimbangan data kemampuan awal, uji normalitas, dan uji homogenitas. Selanjutnya melakukan analisis data dengan langkah-langkah sebagai berikut : 1) Merumuskan hipotesis statistic, 2) Taraf signifikansi, $\alpha=5 \%, 3$ ) menghitung F rasio, 4) membandingkan Frasio dengan Ftabel, 5) penarikan kesimpulan

\section{Hasil Dan Pembahasan}

Penelitian ini merupakan penelitian ekseprimen semu yang dilakukan terhadap siswa kelas VII SMP dari beberapa sekolah di Kota Yogyakarta pada semester genap tahun ajaran 2017/2018. Berdasarkan hasil uji keseimbangan didapatkan hasil bahwa kemampuan awal siswa pada kelas kontrol maupum kelas eksperimen dalam keadaan seimbang. Hal ini ditunjukkan dari hasil uji t yang diperoleh yang menunjukkan bahwa nilai sig $=0.459>\alpha=0.05$.

Uji prasyarat analisis berikutnya adalah uji normalitas dan uji homogenitas. Uji normalitas menggunakan Lilliefors dan uji homogenitas menggunakan uji Bartlett. Dari hasil pengolahan data dengan bantuan software SPSS 22 diperoleh hasil sebagai berikut :

1 ) Uji normalitas

Untuk kemampuan awal diperoleh nilai $\mathrm{Sig}=0.061>\alpha=0.05$ maka disimpulkan bahwa data kemampuan awal berasal dari populasi yang berdistribusi normal. Sedangkan untuk data posttest, karena nilai Sig $=0.054>\alpha=0.050$ maka disimpulkan bahwa data hasil belajar berasal dari populasi yang berdistribusi normal.

2) Uji homogenitas

Untuk kemampuan awal diperoleh nilai sig $=0.123>\alpha=0.050$ diperoleh kesimpulan bahwa data kemampuan awal kelas ekperimen dan kelas kontrol mempunyai variansi homogen. Sedangkan untuk data hasil belajar, karena nilai sig $=0.801>\alpha=0.050$ maka diperoleh kesimpulan bahwa data hasil belajar kelas ekperimen dan kelas kontrol mempunyai variansi homogen. 
Dalam penelitian ini pengujian hipotesis menggunakan analisis variansi dua jalur dengan sel yang tak sama. Pengujian Hipotesis dengan Kriteria H0 diterima jika thitung $<$ ttabel, pada taraf nyata $\alpha=0,05$ dan $\mathrm{dk}=(\mathrm{n} 1+\mathrm{n} 2-2)$ atau nilai sig $>0,05$. Dari hasil uji Anava 2 arah diperoleh bahwa nilai sig $=0,00<0,05$ yang artinya $\mathrm{H}_{0}$ ditolak. Jika $\mathrm{H}_{0}$ ditolak berarti $\mathrm{H}_{1}$ diterima. Dengan demikian dapat disimpulkan bahwa ada perbedaan nilai postes/ hasil belajar berdasarkan model pembelajaran. Hal ini didukung pula dengan nilai rataan marjinal dari masing masing model pembelajaran, yaitu mean TTW sebesar 11,889 sedangkan mean konvensional sebesar 9,578. Oleh karena itu dapat disimpulkan bahwa model pembelajaran TTW lebih efektif dibandingkan dengan model pembelajaran konvensional.

Pada penelitian ini kedua sampel diberikan perlakuan yang berbeda yakni pada kelas eksperimen diterapkan model pembelajaran TTW sedangkan pada kelas kontrol diterapkan model pembelajaran konvensional. Model pembelajaran TTW mempunyai tiga langkah utama yaitu Think, Talk, dan Write. Saat Think siswa secara individu memikirkan penyelesaian soal-soal matematika yang dihadapi. Pada tahap Think, siswa dituntut untuk berpikir menemukan jawaban secara individu dari pertanyaan tersebut. (Purwaningrum \& Sumardi, 2016). Pada tahap ini siswa diberikan waktu untuk merumuskan jawaban pertanyaan yang diberikan. Dalam hal ini siswa harus memiliki keterampilan berpikir yaitu mengenal masalah, menemukan cara menyelesaikan permasalahan, mengumpulkan dan menyusun informasi yang diperlukan, memahami dan menggunakan bahasa yang tepat dan jelas, menganalisis data, menarik kesimpulan (L. Surayya dkk, 2014).

Setelah proses think siswa mencoba untuk mengutarakan pendapat dan ide yang diperolehnya kepada teman-teman diskusinya (kelompok) dalam tahap talk. Pada tahap talk, siswa berkomunikasi dengan menggunakan kata-kata dan bahasa yang mereka pahami. Siswa menyampaikan ide yang diperolehnya pada tahap think kepada temanteman diskusinya (kelompok). Pemahaman dibangun melalui interaksinya dalam diskusi. Diskusi diharapkan dapat menghasilkan solusi atas masalah yang diberikan. Selain itu, pada tahap ini siswa memungkinkan untuk terampil berbicara (Elida, 2012).

Tahap write Siswa menuliskan hasil yang diperoleh saat berdiskusi agar dapat dipahami oleh semua siswa. Aktivitas selama tahap ini adalah : 1) Menulis solusi terhadap masalah yang diberikan termasuk perhitungan, 2) Mengorganisasikan semua pekerjaan langkah demi langkah, 3) Mengoreksi semua pekerjaan sehingga yakin tidak ada pekerjaan yang tertinggal, 4) Meyakini bahwa pekerjaannya lengkap, mudah dibaca dan terjamin keasliannya (Elida, 2012). 
Berbeda dengan kondisi tersebut, pada pembelajaran konvensional siswa terlihat pasif. Siswa mencermati dengan seksama materi yang disampaikan oleh guru namun pada saat guru bertanya hanya beberapa siswa yang menjawab. Selain itu siswa hanya sekadar menghafal materi yang disampaikan oleh guru, sehingga pada pertemuan selanjutnya siswa sudah lupa dengan materi yang dipelajari pada pertemuan sebelumnya (Medyasari, Muhtarom, \& Sugiyanti, 2017)

Pengujian hipotesis yang kedua memberikan hasil bahwa $\mathrm{Sig}=0.047<0.05$, artinya ada perbedaan nilai postes/ hasil belajar berdasarkan tingkat kemampuan awal tinggi, sedang, rendah. Siswa dengan kemampuan awal tinggi memiliki rata-rata hasil belajar matematika yang lebih tinggi dibandingkan dengan siswa yang memiliki kemampuan awal sedang. Sedangkan siswa dengan kemampuan awal sedang memiliki rata-rata hasil belajar matematika yang lebih tinggi dibandingkan dengan siswa yang memiliki kemampuan awal rendah.

Hal ini dimungkinkan karena siswa dengan kemampuan awal tinggi mempunyai bekal pengetahuan yang lebih memadai sehingga siswa dapat memahami konsep maupun komputasi lebih baik dibandingkan dengan siswa yang memiliki kemampuan awal sedang dan rendah (Ria Tri Krisnawati, 2011). Begitu pula sebaliknya siswa dengan kemampuan awal rendah mempunyai bekal pengetahuan yang minim sehingga konsep matematika tidak terserap dengan baik. Siswa dengan kemampuan awal rendah cukup kesulitan dalam memahami materi baru, karena kesulitan menghubungkan konsep lama dengan konsep baru.

Kemampuan awal tiap siswa yang berbeda memberikan pengaruh yang berbeda pula terhadap hasil belajar matematika. Siswa yang memiliki kemampuan awal tinggi cenderung lebih berprestasi dibandingkan siswa yang memiliki kemampuan awal rendah (Handhika \& Praptiwi, 2012)

Karena pada hipotesis kedua terdapat perbedaan antara kemampuan awal tinggi, sedang dan rendah maka perlu dilakukan uji lanjut pasca anava. Hasil uji pasca Anava memberikan hasil bahwa nilai sig $=0.679>0.05$, ini berarti tidak ada interaksi antara model pembelajaran yang diterapkan dengan tingkat kemampuan awal siswa. Tidak adanya interaksi ini mengindikasikan bahwa karakteristik perbedaan antara model pembelajaran TTW dan konvensional untuk semua tingkat kemampuan awal siswa adalah sama. Terdapat kekonsistenan antara penggunaan model pembelajaran dan kemampuan awal siswa terhadap hasil belajar matematika (Tri Suwarni Widayati, 2009).

Dari penelitian ini dapat disimpulkan bahwa model pembelajaran TTW lebih efektif dibandingkan dengan model pembelajaran konvensional (ceramah). Hal ini dikarenakan 
model pembelajaran TTW menjadikan siswa lebih aktif saat proses pembelajaran. Model pembelajaran ini merupakan model pembelajaran yang memfasilitasi latihan berbahasa secara lisan dan menulis bahasa tersebut dengan lancar. Think-talk-write didasarkan pada pemahaman bahwa belajar adalah sebuah perilaku sosial, karena dalam model ini siswa didorong untuk berpikir, berbicara, dan kemudian menuliskan berkenaan dengan suatu topik. Model pembelajaran think-talk-write digunakan untuk mengembangkan tulisan dengan lancar dan melatih bahasa sebelum menuliskannya dan memperkenankan siswa untuk mempengaruhi dan memanipulasi ide-ide sebelum menuliskannya. Model ini juga membantu siswa dalam mengumpulkan dan mengembangkan ide-ide melalui percakapan terstruktur. Strategi think-talk-write yang dipilih pada penelitian ini dibangun dengan memberikan waktu kepada siswa untuk melakukan kegiatan tersebut (berpikir, merefleksikan dan untuk menyusun ide-ide, dan menguji ide-ide itu sebelum menulisnya).

Penerapan model pembelajaran TTW, siswa dapat menuliskan solusi terhadap masalah/ pertanyaan yang diberikan termasuk perhitungan; mengorganisasikan semua pekerjaan langkah demi langkah, baik penyelesaiannya ada yang menggunakan diagram, grafik, ataupun tabel agar mudah dibaca dan ditinjaklanjuti; mengoreksi semua pekerjaan sehingga yakin tidak ada pekerjaan ataupun perhitungan yang ketinggalan; dan meyakini bahwa pekerjaannya yang terbaik yaitu lengkap, mudah dibaca dan terjamin keasliannya (Yamin dan Ansari dalam Adi \& Harini, 2007).

\section{Kesimpulan}

Berdasarkan uraian di atas, dapat diambil kesimpulan bahwa: (1) model pembelajaran TTW lebih efektif dibandingkan dengan model pembelajaran konvensional. (2) Hasil belajar siswa berkemampuan awal tinggi lebih baik daripada siswa yang mempunyai kemampuan awal sedang dan rendah, dan (3) tidak ada interaksi antara metode pembelajaran dan tingkat kemampuan awal siswa berdasarkan hasil belajar.

\section{Referensi}

Adi, N. R. M., \& Harini, E. (2007). Efektivitas Pembelajaran Think-Talk-Write Terhadap Hasil Belajar Matematika Siswa Kelas VIII SMP N 9 Yogyakarta, dalam Jurnal Wacana Akademika, Vol 1 No 1, 13-22.

Arcana, I Nyoman. (2017). Penanggulangan Kelemahan Dari Model Kuasi Eksperimen Dalam Penelitian Pendidikan Matematika. Laporan Penelitian (tidak diterbitkan). Yogyakarta: Universitas Sarjanawiyata Tamansiswa

Elida, N. (2012). Meningkatkan kemampuan komunikasi matematik siswa sekolah menengah pertama melalui pembelajaran think-talk-write (TTW), dalam Jurnal Infinity, Vol 1 No 2, 178-185. 
Handhika, J., \& Praptiwi, P. (2012). Efektivitas Metode Kooperatif Tipe GI dan STAD Ditinjau dari Kemampuan Awal, dalam Jurnal Penelitian Pembelajaran Fisika, Vol 3 No $1,41-50$.

Huang, H. (2017). Uji Anova, Teori Satu Arah dan Dua Arah - Globalstats Academic. Retrieved from http://www.globalstatistik.com/uji-anova-satu-dua-arah/

Medyasari, L. T., Muhtarom, M., \& Sugiyanti, S. (2017). Efektivitas Model Pembelajaran Group Investigation Berbantuan Kartu Soal, dalam Jurnal Aksioma, Vol 8 No 1, $65-75$.

Purwaningrum, D., \& Sumardi, S. (2016). Efek strategi pembelajaran ditinjau dari kemampuan awal matematika terhadap hasil belajar matematika kelas xi ips, (1), $155-167$.

Ria Tri Krisnawati. (2011). Eksperimentasi Pembelajaran Matematika dengan Pendekatan Think Pair Share (TPS) dan Think Talk Write (TTW) pada Pokok Bahasan Persamaan dan Pertidaksamaan Kuadrat Ditinjau dari Kemampuan Awal Siswa Kelas X Pada Sekolah Menengah Atas Kota Surakarta Tahun Pelajaran 2010-1011. Tesis. Surakarta : Prodi Pendidikan Matematika Program Pascasarjana UNS.

Siregar, Sofyan. (2012). Model Penelian Kuantitatif. Jakarta: Kencana Prenada Media Group.

Surayya, L., Subagia, I. W., \& Tika, I. N. (2014). Pengaruh model pembelajaran think pair share terhadap hasil belajar IPA ditinjau dari keterampilan berpikir kritis siswa. E-Journal Program Pascasarjana Universitas Pendidikan Ganesha, 4, 1-11. Diakses pada 31 Mei 2018 dari http://pasca.undiksha.ac.id/ejournal/index.php/jurnal_ipa/article/download 1105/853

Tri Suwarni Widayati. (2009). Efektivitas Model pembelajaran Portofolio Terhadap Hasil Belajar Matematika Ditinjau dari Sikap Siswa Terhadap Matematika Kelas XI IPS SMA Negeri di Kabupaten Klaten Tahun Pelajaran 2008 - 2009. Tesis. Surakarta : Program Pascasarjana UNS.

Usman, Husaini. (2009). Pengantar Statistika. Jakarta: Bumi Aksara 